\title{
Political Priority and Policy Process: A Recent Example from Bangladesh
}

\author{
Golam Rabbani (Corresponding author) \\ Lecturer, Department of Public Administration \\ University of Rajshahi, Rajshahi-6205, Bangladesh \\ E-mail: rabbaniea@yahoo.com \\ Harold Sougato Baroi \\ Lecturer, Department of Public Administration \\ University of Rajshahi, Rajshahi-6205, Bangladesh \\ E-mail: sarothi_baroi@yahoo.com
}

Received: June 23, 2011

Accepted: July 27, 2011

Published: January 1, 2012

doi:10.5539/ass.v8n1p247

URL: http://dx.doi.org/10.5539/ass.v8n1p247

\begin{abstract}
Political priority is one of the most important elements in agenda setting as it mirrors the interest of political actors to take a specific problem over others. Not only at the agenda setting stage but political priority also plays a significant role in policy formulation, implementation and evaluation. Kingdon in his Stream Model emphasised on three elements i.e. problem stream, proposal stream and politics stream, and for a successful agenda setting it is essential that these three steams come together and turned into a policy decision. This article is an effort to see how political priorities and political commitments make a specific problem as policy agenda and contribute to the cause.
\end{abstract}

Keywords: Public policy, Political priority, Health, Community clinic

\section{Introduction}

Policy actors deal with lots of policy problems during the stage of agenda setting. A specific problem takes place as an agenda item in the process when that problem is accepted as a real problem. Diversity, extent and consequence of the problem in the life of common people were popular indicators to measure the weight of the policy problem (Dery, 2000). Scholars proved that policy makers' knowledge on severity of the problem and availability of potential solutions is pre-condition for taking decision on specific policy issue, because they have thousands of issues to confront, and scarce resources. Political priority is not only important in agenda-setting (Note 1) phase but also important in other phases, like- policy formulation, policy implementation and evaluation. Recognizing the problem is not necessary guarantees that the government will implement programmes effectively providing financial and other resources (Shiffman \& Ved, 2007; Spiller, Stein \& Tommasi, 2003).

Political priority refers to the degree to which political leaders consider a specific problem significant among the existing problems, with the allocation of financial, human and technical resources significant enough to encounter the severity of the problem (Shiffman \& Ved, 2007). As we understand priority is meaningful when (1) national political leaders openly express grave concern for specific problem; (2) the Government consider the problem using an official decision-making process and (3) the Government allocates and disburse fund to commensurate with the problem's gravity (Shiffman, 2007).

John Kingdon's streams model was used as a framework in this paper to explain the emergence of political priority for community health in Bangladesh. Kingdon challenges conventional models of the public policy process which are known as rational and linear. He explained that agenda-setting has a random character and is unpredictable (Cited in, Shiffman \& Ved, 2007). Also, Kingdon described that policy processes are neither elite nor pluralist in their entireties. Instead, completion was found in separate "streams" of policymaking activity among pluralist forces and elite forces. According to Kingdon's view, an issue becomes an agenda item with the 
confluence of three "streams": the problem stream, the proposal stream and the politics stream (Laraway \& Jennings 2002)

The problem stream refers to the process which indentifies one problem over others. This process also describes condition of a specific problem in society through data or indicators. In this stream, different actors try to influence the policy makers by highlighting the problems with different findings and evidence. Secondly, the proposal stream produces the set of alternative proposals to solve the problem. In this stream proposals are generated, debated, revised, and adopted for serious consideration by policy actors. They expressed their ideas through various public forums (seminars, public meetings) and writings. Policy makers accepted these proposals which are seen as technically feasible, compatible with political values, reasonable in cost, and appealing to the public. Finally, there is a political stream. The political stream consists of elements such as changes in elected officials, political context or mood, and the voices of advocacy or opposition groups.

These three elements operate independently, although the actors in each can overlap. Successful agenda setting requires that three steams come together at a critical time and then a "policy window" opens. (Kalu 2005, Kelly 2005). Through this window specific agenda items become subject of policy decision.

\section{Methods}

Mixed method approach (both quantitative and qualitative) has been used in this study. To analyze the role of political priority in policy process of Bangladesh case study is an ideal methodology since holistic and in-depth investigation is possible through this method (Feagin, Orum \& Sjoberg, 1991). In this research, an exploratory and descriptive case study approach was used because how, what, and why questions have been posed. Both primary and secondary data have been collected to explain the objectives of the study. Sample sizes were determined on the basis of the principles of Snowball Sampling and fifteen individuals were selected as respondent. In this technique, first subject was identified with serious attention and then the respondent was asked to identify the other potential subject. For the most part, qualitative data was used in this study supplemented by quantitative data whenever appropriate. In Creswell's term (1994:177), this could be termed as a dominant - less dominant design. Here, the dominant design is the qualitative data, while the less dominant one is quantitative data. Primary data were collected through a semi-structured interview questionnaire having both closed and open-ended questions. Secondary materials were gathered from different published sources such as, books, book chapters, articles, unpublished dissertations, newspapers, and internet browsing. Key Informant Interview guidelines were pre -tested. In this study one respondent's view was cross-cheeked with other respondents. Also primary data was re-cheeked with relevant secondary data. Denzin (1978) used the term "triangulation" to argue for the combination of methodologies in the study of similar phenomena. Thus, effort was made to use a combination of qualitative and quantitative methods in a single research.

\section{Results}

Since independence, all the ruling parties have taken Primary Health Care (PHC) as one of the priority sectors for national development and carried on various policies for achieving Health for All (HFA). Although, broadly, the policy priority of each political party is the same, strategically they differ. The Awami League (Note 2) (hereinafter, AL) has always given preference to establishing community-level health facilities. In the first general election, held in 1973, Awami League pledged to accelerate family planning programmes and establish rural health centres. These commitments of AL have been reflected in the First Five Year Plan (1973-1978). Accordingly, the construction of health centres at the Union (Note 3) level and health complexes (31- bed hospitals) at the thana (sub-district) level began (Osman, 2004; Osman, 2008). At first, the Bangladesh Nationalist Party (Note 4) (hereinafter, BNP) Government were more explicit about urban hospital-based care. Although, in the 1979 election, BNP gave priority to preventive care and rural health, in the 1996 election, they gave priority to curative care (Osman, 2004).

In 1977, the Government felt the need for private sector participation in health service delivery, which was reflected in the interim Two Year Plan (1978-80) and in the Second Five Year Plan (1980-85). The Third Five Year Plan (1985-90) added a new dimension in health services, by focusing on Maternal and Child Health $(\mathrm{MCH})$ as an effective means of population control, and community-based services were started. The Fourth Five Year Plan (1990-95) also emphasized MCH services, along with a focus on primary healthcare and EPI (Expanded Program on Immunization) clinics. The Fifth Five Year Plan (1997-2002) added certain new strategic issues under the influence of the Health and Population Sector Strategy (HPSS) adopted in 1997 (Osman, 2004 \& Osman, 2008) to provide community-based health services.

In this connection, 11,159 community clinics were built during 1999-2001, to provide Essential Service Package (ESP) services to the rural poor but, by 2004, not one community clinic was functioning (The Daily Star, 29 
April, 2004). One of the major causes was that the new BNP Government (2001-2007) did not find the community clinics so valuable. It was argued that "Community clinics were considered to be ineffective and an enormous financial burden, which was getting increasingly difficult for the government to maintain." (Cited in BHW 2010).

Also, the BNP Government found that Family Planning (FP) staff constitute the core of Bangladesh's health service, as they have been in close contact with the people through their door-to-door services. By offering one-stop service points, community clinics threatened to limit door-to-door service provision, thereby weakening field-level activities and reducing contact with the people. In spite of having a strong argument from the minister of BNP saying that the land that was used for the clinics were donated by the community themselves, it was found that the sites were not always easily accessible. The Government de-emphasised the clinics and soon there was a chronic absence of staff, basic medical supplies, etc. (Cited in BHW 2010).

After the end of the BNP regime, in 2007, a new interim Caretaker Government (CG) sought to update health policy. According to the respondents of the study, this policy formulation process goes back to the term of the interim caretaker Government (Note 5) (2007-09). The then Health Advisor (Note 6) of the Caretaker Government of Bangladesh, Dr. A M M Shawkat Ali, declared the formulation of new health policy within the following three months during a meeting on the World Health Day observation to provide better health services to the poor and disadvantaged people ( The Daily Star, 07 April 2008). The following sections highlighted the role political priority in problem recognition, accepting proposal and accommodating the solution as authoritative decision as well as resource allocation.

\subsection{Problem Stream}

Most of the respondents viewed the situations of maternal health and child health, problems of health service providers, cost of health service, health services in remote area, women- friendly health service and HIV/AIDS issues to be the dominant factors for highlighting the community health issues as a problem in the agenda setting process of health service (Interview). Maternal health situation is one of the important indicators of achieving Millennium Development Goal (MDG)-4. Presently the antenatal care from a qualified contributor who has medical training has increased to 52 percent. There are disparities in urban - rural settings in antenatal care. 71 percent of mothers are getting antenatal care in urban region while it is only 46 percent in the rural areas (BDHS, 2007). Same study findings (BDHS, 2007) shows that women in urban areas are three times as likely as women in rural areas to give birth in a health facility. According to MICS 2009 report, Under 5 Mortality Rate in rural and urban areas are respectively 70 and 58 percent. The gap in awareness of HIV is much higher in rural area. Urban women (87\% have basic knowledge) are more knowledgeable than their rural counterpart (BDHS, 2007).

Qualified health service providers, and their presence in the service-providing locations, are important indicators for providing quality health service in Bangladesh. In the rural areas of Bangladesh, absenteeism of doctors is $40 \%$ at the Upazila Health Centres (UPCs) and in the Union Health and Family Welfare Centre (UHFWC) it is as high as $74 \%$ (Chowdhury and Hammer, 2004). Rural areas have a much higher density (170 per 10,000 population) than urban areas (81 per 10,000 population) when all types of providers are considered. There is also a huge urban-rural difference in the presence of different provider groups. In fact, the majority of qualified providers in addition to the physicians, such as nurses, dentists, technicians etc. practice in urban areas (BHW, 2008).

Findings of above mentioned revealed that health situation and care service scenario in Bangladesh is not good in rural areas. To improve the health condition of rural people of Bangladesh, AL Government first introduced the community clinics at village level in 1999-2000. Again this problem was recognised by its election manifesto, 2008 .

\subsection{Proposal Stream}

Since 2008, different types of actors, especially the stakeholders of health sectors, have been very active to promote their policy solutions. We asked the respondents about different solutions which had been proposed by the different policy actors to solve the community health problem in Bangladesh. Respondents expressed the view that community clinics, health education, door-to-door service, creation of semi-skilled manpower, incentives for medical professionals, use of alternative indigenous treatment along with modern medical treatment, skill development of unskilled or semi-skilled practitioners and mobile medical services, etc were the significant proposals for improving the community health situation in Bangladesh from both sate and non-state actors (Interview with policy actors and content of written document of MoHFW). 
If top political leaders of the ruling Party take initiatives to promote a problem or proposal, then that problem or proposal gets priority promptly. According to the team leader of the PSO, HNPSP, MoHFW, the Party leaders of the new Awami League Government, elected in 2008, were very much interested in preparing a health policy and promoting the community clinic agenda, as well as giving direction about the strategic part of the policy content. Also, the Health Minister publicly promised that his Government would build one community clinic in each village (The Daily Star; January 10, 2009). One of the Ex-Directors, DGHS, MoHFW said that the Government were committed to national and international declarations or standards. So, the Government must be compliant with these national and international commitments (Source: Interview).

Some people were again criticising that community clinics would interfere with the policy of home visits and that the clinics were not convenient to the village residents. Speaking at the workshop as the chief guest, State Minister for Health and Family Welfare Mozibur Rahman Fakir said it was not possible to provide health service to 20,000 people through a union health complex and, he gave importance on community clinic (Note 7).

\subsection{Politics Steam}

While the CG were formulating the policy draft, AL arranged a press conference. At this conference, AL's Health and Population Secretary, Dr Mostafa Jalal Mohiuddin, stressed the AL's commitment to the community clinics in Bangladesh. (The Daily Star, 18 September 2008). According to the majority of survey respondents, the AL includes a number of health professionals and they are very much enthusiastic to promote the community clinic issues as a means of ensuring the health rights of the village people of Bangladesh (Interview with respondents). Also, as a political party, AL had a commitment to the people to establish the community clinics for the betterment of the common people. The Election Manifesto of AL in 2008 highlighted the community clinic in the following way:

"In order to ensure health facilities to every citizen of the country, the health policy of the former Awami League Government will be re-evaluated and adjusted according to the demands of the time. In the light of this policy, 18,000 community clinics, established during Awami League rule, will be re-commissioned."[Election Manifesto of AL in Election 2008]

In the political system of Bangladesh the Prime Minister is the supreme policy decision maker and head of the ruling party. Sheikh Hasina, the Prime Minister, back in office after an 8-year absence, took up the community clinic issue and often made promises to resuscitate the community clinics, even after the election (The Daily Star, 10 January 2009; The Daily Star, 05 May 2010, The Daily Star, 1 November 2009). The National Health Policy announced in 2010 was the result.

Politicians had their own motivations for introducing the policy. There was a prospect of many jobs at the local level and expenditure of a lot of money, which would win local votes. Very recently Health Adviser to the Prime Minister while answering questions of pressmen stated that he would recruit his party men in the post of 13500 health workers under his ministry. He also stated that he has already developed a mechanism to implement his strategy to recruit AL supporters. (The Daily Independent, 2 October, 2010). This also generated a support for the policy outside the Ministry.

\section{Success Breeds Success}

The Awami League Government of 1996-2000 created the community health clinics policy, which collapsed. In 2010 , they created almost the same policy but it succeeded. What is the difference?

The difference is that the 2009-2013 Government had enough time to implement the community health policy and make it successful. In 2000, they were out of office in less than a year. Now, delivering tangible results in the villages, the policy has generated its own support and probably cannot be repealed by any subsequent Government.

Since the taking of oath of the current government on January 06, 2009, the Ministry of Health and Family Welfare took initiatives to revitalise the community clinics. Re-opening of the community clinics was one of major commitment of the ruling party in the 2008 National Election. Of the 18,000 planned community clinics, 9,722 have already been re-opened. For building the additional community clinics to fulfil the 18,000 targets and strengthening their operations, Government has approved a 5-year long new project called "Revitalization of Community Health Care Initiatives in Bangladesh". The proposed fund allocation of the project is 26,774.90 million taka (Note 8). 


\section{Conclusion}

In this study, it is found that, as a political party, AL made a commitment, in their election manifesto of 2008 , that they would restart the community-level health clinics. Moreover, top-level policy-makers, including the Prime Minister and Health Minister, were enthusiastic to promote the community health issues that they had publicly addressed.

It can be concluded that, in the problem stream, evidence production and dissemination were highly-supportive in highlighting the problems of community health issues as policy agenda. These problems were highlighted in different documents of governments, NGOs and donors. Moreover, these problems were recognised by politicians and other key policy actors (donors and bureaucrats). In the proposal stream, national and international policy coherences, international and national good practices and positive attitudes of donors were among other factors that supported the community clinics as a policy proposal. Also, political support of the ruling party (AL) was positive, to highlight the community clinic and community health issues. So, it can be said that political ideology, political commitment of the top leaders and positive national mood were the main factors in highlighting the policy problems and proposals as agenda for further decision making in the health sector.

\section{References}

BDHS. (2007). Bangladesh Demographic and Health Survey 2007. National Institute of Population Research and Training (NIPORT), Mitra and Associates, and Macro International. 2009. Dhaka, Bangladesh and Calverton, Maryland, USA: National Institute of Population Research and Training, Mitra and Associates, and Macro International.

BHW. (2008). Health Workforce in Bangladesh: Who Constitutes the Healthcare System? The State of Health in Bangladesh 2007, Dhaka: James P. Grant School of Public Health, BRAC University.

BHW. (2010). How Healthy is Health Sector Governance? Bangladesh Health Watch Report 2009, Dhaka: The University Press Limited and Bangladesh Health Watch.

Creswell, J. W. (1994). Research Design: Qualitative and Quantitative Approaches. London: Sage Publications.

Denzin, N. K. (1978). The Research Act: A Theoretical Introduction to Sociological Methods, (2nd Ed.). New York: McGraw-Hill.

Dery D. (2000). Agenda Setting and Problem Definition. Policy Studies, Vol. 21, No. 1, 37-47. http://dx.doi.org/10.1080/014428700114008

Feagin, J., Orum, A. \& Sjoberg, G. (eds.) (1991). A Case for Case study. Chapel Hill, NC: University of North Carolina Press.

Kalu K. N. (2005). Competing Ideals and the Public Agenda in Medicare Reform: The "Garbage Can" Model Revisited. Administration \& Society, 37, 23-56. http://dx.doi.org/10.1177/0095399704272593

Kelly B. (2005). John Kingdon's Theory at the State Level: A Look at Preschool for All in Illinois and California. [Online] Available: www.crocus.georgetown.edu/reports/CROCUS workingpaper5.pdf (May 17, 2008)

Laraway A. S. and Jennings C. P. (2002). Health Insurance Flexibility and Accountability Demonstration Initiative (HIFA): A Policy Analysis Using Kingdon's Policy Streams Model. Policy Politics and Nursing Practice, 3, 358-366. http://dx.doi.org/10.1177/152715402237970

Manifesto of AL in Election 2008.

MICS. (2009). Multi-indicator Cluster Survey, 2009. BBS, UNICEF, GOB, Dhaka.

Osman F.A. (2004). Policy Making in Bangladesh: a study of the health policy process. Dhaka: AHDP.

Osman, F. A. (2008). Health Policy, Programs and System in Bangladesh: Achievement and Challenges. South Asian Survey, (15)2:23-288.

Shiffman J. \& Ved R. (2007). The state of political priority for safe motherhood in India. BJOG, 114:785-790. http://dx.doi.org/10.1111/j.1471-0528.2007.01374.x

Shiffman J. (2007). Generating political priority for maternal mortality reduction in five developing countries. American Journal of Public Health, 97:796-803. http://dx.doi.org/10.2105/AJPH.2006.095455

The Daily Independent (A national English daily in Bangladesh), 2 October, 2010.

The Daily Star (A national English daily in Bangladesh), 1 November 2009.

The Daily Star (A national English daily in Bangladesh), 05 May 2010. 
The Daily Star (A national English daily in Bangladesh), 07 April 2008.

The Daily Star (A national English daily in Bangladesh), 10 January 2009.

The Daily Star (A national English daily in Bangladesh), 18 September 2008.

The Daily Star (A national English daily in Bangladesh); 10 January, 2009.

\section{Notes}

Note 1. In agenda-setting phase in the public policy process, certain problems draw the attention of policy makers while others recede or are ignored completely

Note 2. One of the major political parties of Bangladesh

Note 3. Lowest tire of the local government system in Bangladesh

Note 4. One of the major political parties in Bangladesh

Note 5. The caretaker government of Bangladesh is a form of government system in which the country is ruled by a selected government for an interim period during transition from one government to another, after the completion of the tenure of the former.

Note 6. In the interim caretaker Government, advisors take the place of Ministers, but they are not Members of Parliament and are meant to be apolitical.

Note 7. Source : http://www.thedailystar.net/newDesign/news-details.php?nid=140823, accessed on 12.04.2010

Note

8.

Source:

http://nasmis.dghs.gov.bd/dghs_new/dmdocuments/All/Primary\%20Health\%20Care\%20in\%20Bangladesh.pdf

(March 22, 2011) 